\title{
Root system architecture in winter varieties of spelt (Triticumspelta L.)
}

\author{
Andrzej Żabiński ${ }^{1}$, and Urszula Sadowska ${ }^{1}$ \\ ${ }^{1}$ University of Agriculture in Krakow, Faculty of Production and Power Engineering Institute of Machinery Exploitation, Ergonomics \\ and Production Processes, Poland
}

\begin{abstract}
The objective of the study was determination of the variability of morphometry and comparison of the morphological structure of the root system in winter cultivars of spelt. Four spelt cultivars were used in the study: Frankencorn, Oberkulmer Rotkorn, Schwabenkorn and Ostro. The material for the study originated from a field experiment. The roots were collected using the soil core method to the depth of $30 \mathrm{~cm}$, from the rows and inter-rows, then the roots were separated using a semiautomatic hydropneumatic scrubber. The cleaned roots were manually separated and scanned, obtaining their digital images. Image analysis was performed using the Aphelion computer software. In order to characterize the root system of the spelt cultivars included in the study, values of the following indexes were determined: root dry mass (RDM), root length density (RLD), specific root length (SRL), mean root diameter (MD). Based on the obtained results it was determined that the RDM, MD and RLD indexes in all spelt cultivars attain the highest values in the row, at the depth $0-5 \mathrm{~cm}$. The highest value of the RDM and MD indexes characterized the root system of the Ostro cultivar at the depth $0-5 \mathrm{~cm}$. The Oberkulmerrotkorn spelt cultivar was distinguished among the tested objects by the highest value of the SRL index.
\end{abstract}

\section{Introduction}

Spelt (Triticumaestivumsspspelta L.) is a species included in the Poaceae family. It is one of the oldest wheat subspecies, which survived practically unchanged to the modern times. For centuries, it was the dominant cereal in Europe, cultivated in areas featuring cool climate: in Scandinavia, mountainous Germany, Switzerland and Poland. In the EU as well as Polish legislation spelt is considered to be a separate species (Triticumspelta L.) [1]. This cereal has gained increasing attention in recent years due to the possibility for cultivation under extensive conditions. In addition, its nutritional values are also appreciated. Spelt contains high amounts of essential nutrients such as proteins, unsaturated fatty acids, carbohydrates, vitamins and bioelements, as well as fiber, which supports body purification, distinguishing it from other cereals [2, 3]. Considering the increasing interest in spelt, primarily in the organic farming sector, a need has arisen for the study of natural characters of the existing cultivars of the cereal, determining the possibility to obtain satisfactory results of its cultivation in terms of qualitative as well as quantitative of the grain. The root system is the plant's organ with a highest impact on this issue.

Research on the root systems constitutes the basic method for the evaluation of plant growth. Twisting, elongation and branching are three basic cellular processes in roots, which constitute the basis for the architecture of the root system. Together, these elements determine the distribution of roots in the soil environment, thus determining the access to water and nutrients by the plant and its anchoring in the substrate [4]. Roots determine the proper course of the key plant physiological processes, such as photosynthesis and gas exchange [5]. Information on the root systems of crops are the foundations for the efficient water resources and nutrient management. Understanding of the development and architecture of a root system is the basis for the optimization of arable land use and increase in the efficiency of the plants cultivated on them. One of the indexes commonly considered in analyzes of root systems is the root length density (RLD). Its values are important for the modeling process of the movement of water and nutrients in the aeration zone and for the study of soil-root-stem-air interaction $[6,7,8,9]$.

\section{Materials and methods}

The study was conducted in a 2-year period as a field experiment, located in Mydlniki near Krakow (latitude $50^{\circ} 04^{\prime} \mathrm{N}$ longitude $19^{\circ} 51^{\prime} \mathrm{E}$ ) at the Institute of Machinery Exploitation, Ergonomics and Production Processes of the University of Agriculture in Krakow. The climatic conditions of the area where the study was conducted are characterized by monthly accumulated rainfall and average monthly temperatures in years 2012-2013, 
presented in Table 1. The presented data originate from the meteorological station located at a distance of about $3 \mathrm{~km}$ from the study area. The experimental site is characterized by a moderate-continental climate. The experiment was set up in individual years on a soil with the granulometric composition of clay sand, belonging to the good rye soil complex.

The study included 4 winter spelt cultivars. Frankenkorn, Schwabenkorn, Oberkulmer Rotkorn and Ostro. The forecrop for spelt ever year was white mustard, sown as an aftercrop intended as green manure. The surface area of the fields for individual objects was $4 \mathrm{~m}^{2}(2 \mathrm{~m} \times 2 \mathrm{~m})$. The fields were separated with pathways, width $1.5 \mathrm{~m}$. Mineral fertilization was used under plants at the following dosages of pure components: $\mathrm{N}-70 \mathrm{~kg} \cdot \mathrm{ha}^{-1}, \mathrm{P}_{2} \mathrm{O}_{5}-60 \mathrm{~kg} \cdot \mathrm{ha}^{-1}, \mathrm{~K}_{2} \mathrm{O}-75$ $\mathrm{kg} \cdot \mathrm{ha}^{-1}$. Phosphorus-potassium fertilizers were sown in autumn during forecrop cultivation, nitrogen was used during plant vegetation in spring. Spelt was sown in the first third of October. Sowing was performed manually into rows, at $12 \mathrm{~cm}$ spacing. The assumed plant density was $250 \mathrm{pcs} \cdot \mathrm{m}^{-2}$.

The soil samples with roots were obtained from the experimental fields at the stage of mature waxy soft kernels (BBCH 85). They were collected separated from the rows and inter-rows in 3 repetitions within each cultivar, using the soil-core method [10]. The core diameter was $80 \mathrm{~mm}$. The soil and root samples were obtained to the depth of $30 \mathrm{~cm}$, then separated into layers: $0-5,5-10,10-15,15-20,20-25$ and $25-30 \mathrm{~cm}$. In order to remove the soil particles, roots were cleaned using hydropneumatic elutriation [11]. The air pressure utilized during cleaning was approximately $300 \mathrm{kPa}$. The cleaning time of each sample was $3 \mathrm{~min}$. In order to remove excess water from the cleaned roots, they were transferred and placed on filter paper. Subsequently, the roots were manually separated, removing all remaining contaminants. The separated and cleaned roots were then placed in the scanner. Digital images were obtained using Epson Perfection 4870 Photo (scanner by Seiko Epson Corp., Suwa, Nuagano, Japan), recording them in TIFF format at the 600 dpi resolution. Example image of scanned roots is presented in figure 1.

Table 1. Monthly and annual temperatures and accumulated rainfall for the study period and long-term averages.

\begin{tabular}{|c|c|c|c|}
\hline \multirow{2}{*}{} & $\mathbf{1 9 6 1 - 9 9}$ & $\mathbf{2 0 1 2}$ & $\mathbf{2 0 1 3}$ \\
\cline { 2 - 4 } & \multicolumn{3}{|c|}{ Monthly average temperature [ $\left.{ }^{\mathbf{0}} \mathbf{C}\right]$} \\
\hline January & $-3,3$ & $-0,1$ & $-2,4$ \\
\hline February & $-1,6$ & $-5,5$ & $-0,5$ \\
\hline March & 2,4 & 5,8 & $-0,9$ \\
\hline April & 7,9 & 12,3 & 8,9 \\
\hline May & 13,1 & 15,3 & 14,3 \\
\hline June & 16,2 & 20,0 & 17,5 \\
\hline July & 17,5 & 21,0 & 19,4 \\
\hline August & 16,9 & 19,1 & 19,1 \\
\hline September & 13,1 & 14,8 & 12,0 \\
\hline October & 8,3 & 8,5 & 9,9 \\
\hline November & 3,2 & 4,7 & 4,9 \\
\hline December & $-1,0$ & $-0,8$ & 1,2 \\
\hline Annual mean & 7,7 & 9,6 & 8,6 \\
\hline
\end{tabular}

\begin{tabular}{|c|c|c|c|}
\hline & \multicolumn{3}{|c|}{ Precipitation [mm] } \\
\hline January & 34 & 52 & 62 \\
\hline February & 32 & 27 & 22 \\
\hline March & 34 & 23 & 32 \\
\hline April & 48 & 43 & 20 \\
\hline May & 83 & 23 & 99 \\
\hline June & 97 & 144 & 213 \\
\hline July & 85 & 64 & 27 \\
\hline August & 87 & 55 & 26 \\
\hline September & 54 & 42 & 86 \\
\hline October & 46 & 97 & 14 \\
\hline November & 45 & 24 & 71 \\
\hline December & 51 & 26 & 22 \\
\hline Annual sum & 696 & 620 & 694 \\
\hline
\end{tabular}

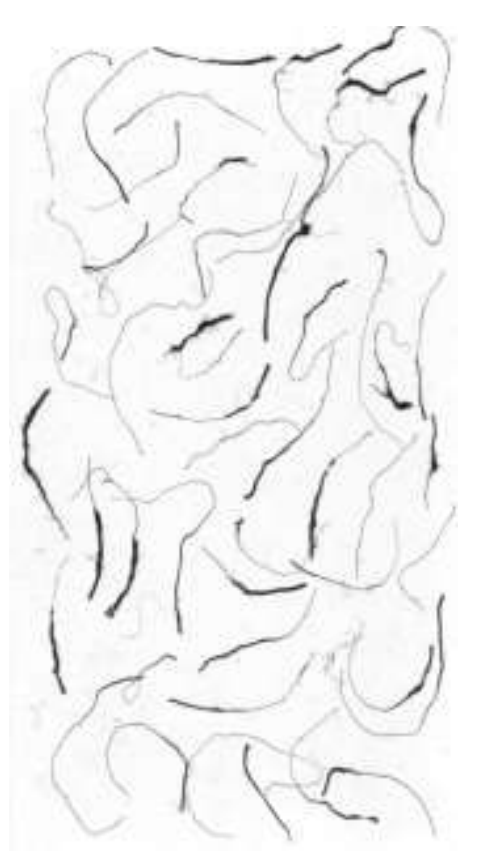

Fig.1. Example image of scanned spelt roots of the Oberkulmer Rotkorn cultivar, obtained from the depth of $0-5 \mathrm{~cm}$.

The root images were subjected to analysis using the APHELION v3.2 software, following the methodology described by Bauhus and Messier [12]. The measured root length was separated into eight diameter classes: 0 $0.02 ; 0.02-0.05 ; 0.05-0.1 ; 0.1-0.2 ; 0.2-0.5 ; 0.5-1.0$; $1.0-2.0 ;>2.0$. Root length density (RLD) was calculated dividing the total root length in the soil sample by the sample volume. Specific root length (SRL) was calculated by dividing the RLD by the dry mass of the roots. The mean root diameter (MD) was calculated as a weighted average of root lengths for individual diameter classes. After scanning, the roots were dried at temperature $70^{\circ} \mathrm{C}$ to determine their dry mass. Root dry mass (RDM) was calculated dividing the root dry mass in the soil sample by the sample volume.

In the period of obtaining soil-root samples the soil penetration resistance was also recorded using the STIBOKA penetrometer (EjkelkampAgrisearch Equipment, the Netherlands), with a conical base with the surface of $100 \mathrm{~mm}^{2}$ and the apex angle $60^{\circ}$ [13]. 
Results of the spelt root system study were statistically elaborated using the Statistica 12 software. In order to evaluate the significance of the differences between the means a Duncan test was used at the significance level of $\mathrm{p}=0.05$, distinguishing homogeneous groups.

\section{Results and discussion}

Results of the measurement of soil penetration resistance on the experimental fields are provided in table 2 . Analysis of the obtained values of the parameter demonstrated that on the depth of 25 and $30 \mathrm{~cm}$ the resistance for the penetrometer probe is highest and it does not exhibit variability in statistical terms. Its mean value for these depths was $3.494 \mathrm{MPa}$. In higher layers of soil, at depths of 10,15 and $20 \mathrm{~cm}$, the resistance was significantly lower and amounted to $2.685 \mathrm{MPa}$ on average. The lowest value of penetration resistance was registered at the depth of $5 \mathrm{~cm}$, where it was $1.345 \mathrm{MPa}$ (Table 2).

Table 2. Soil penetration resistance at a given depth.

\begin{tabular}{|c|c|}
\hline Depth (cm) & $\begin{array}{c}\text { Soil penetration resistance } \\
\text { (MPa) }\end{array}$ \\
\hline 5 & $1,354 \mathrm{~d}^{*}$ \\
\hline 10 & $2,228 \mathrm{c}$ \\
\hline 15 & $2,771 \mathrm{~b}$ \\
\hline 20 & $3,056 \mathrm{bc}$ \\
\hline 25 & $3,254 \mathrm{a}$ \\
\hline 30 & $3,735 \mathrm{a}$ \\
\hline
\end{tabular}

*a, b, c, d-homogeneous groups according to the Duncan test

The performed analysis of variance of the RDM index describing the root dry mass exhibited interaction between individual cultivars and the vertical distribution of roots in the soil. The RDM index attained highest values at depth from 0 to $5 \mathrm{~cm}$ for the Ostro cultivar, where the mean value was $0.0023 \mathrm{~g} \cdot \mathrm{cm}^{-3}$. The remaining cultivars in the discussed soil layer were characterized by lower root dry mass amounting to the mean 0,0015 $\mathrm{g} \cdot \mathrm{cm}^{-3}$. In the deeper soil layers $(5-30 \mathrm{~cm})$, the discussed index did not exhibit any statistically significant differences between the tested cultivars and its mean value was $0.0002 \mathrm{~g} \cdot \mathrm{cm}^{-3}$ (Table 3).
The root dry mass index further exhibited variability depending on the depth and sampling site. At the depth between 0 to $5 \mathrm{~cm}$, higher root mass was determined in samples obtained from rows as compared to inter-rows (Table 3). This can be explained by the thicker initial and seminal roots with higher mass present in this zone.

The index for specific root length (SRL) is one of the most commonly determined morphological parameters of fine roots. It characterizes economic aspects of a root system, linked to the capability to absorb water and nutrients. The SRL index is negatively correlated to the root thickness. Higher value of the SRL index means thinner roots, thus their greater surface area. Root systems with a high value of the SRL index possess better contact with the soil, thus increasing their absorption potential [14, 15]. Under suboptimal concentrations of nutrients in soil, large root surface area is favorable, as it facilitates absorption of less mobile components, such as phosphorus (P) [16]. In the study conducted by Løes and Gahoonia [17], concerning root systems of spring wheat and barley, the obtained mean values of the SRL index under the conditions of soil cultivation were 30000 and $26300 \mathrm{~cm} \cdot \mathrm{g}^{-1}$, respectively. Corneo et al., [18], who determined, among others, value of this index among 23 genotypes of wheat, belonging to different breeding groups observed that in the layer 0-30 $\mathrm{cm}$ it ranges from 2895 to $8962 \mathrm{~cm} \cdot \mathrm{g}^{-1}$. For the tested spelt cultivars the mean value of specific root length in the $0-30 \mathrm{~cm}$ layer remained at the level of $13291.9 \mathrm{~cm} \cdot \mathrm{g}^{-}$ ${ }^{1}$, not exhibiting variation on specific depth levels (Table 4). But, significant differences were observed for the values of this index between individual cultivars. The highest specific root length characterized the Oberkulmer Rotkorn cultivar, for which the mean value of the parameter was $14873.6 \mathrm{~cm} \cdot \mathrm{g}^{-1}$. The cultivars: Ostro and Schwabenkorn were characterized by similar values of the SRL index, whose mean value for these cultivars was $13114.7 \mathrm{~cm} \cdot \mathrm{g}^{-1}$. The lowest specific root length with the value of $12064.674 \mathrm{~cm} \cdot \mathrm{g}^{-1}$ characterized the Franckenkorn cultivar. The SRL index also exhibited statistically significant variation depending on the depth and sample collection site. For the depth $0-5 \mathrm{~cm}$ and samples obtained from row, the specific root length was lowest, attaining the value of $4357.6 \mathrm{~cm} \cdot \mathrm{g}^{-1}$ (Table 4).

Table 3. Index values describing the root dry mass (RDM).

\begin{tabular}{|c|c|c|c|c|c|c|c|}
\hline \multirow{2}{*}{ Cultivar } & \multirow{2}{*}{$\begin{array}{c}\text { Collection } \\
\text { site }\end{array}$} & \multicolumn{6}{|c|}{ RDM $\left(\mathrm{g} \cdot \mathrm{cm}^{-3}\right)$ for the depth } \\
\hline & & $0-5 \mathrm{~cm}$ & $5-10 \mathrm{~cm}$ & $10-15 \mathrm{~cm}$ & $15-20 \mathrm{~cm}$ & $20-25 \mathrm{~cm}$ & $25-30 \mathrm{~cm}$ \\
\hline Franckenkorn & & $0,00146 \mathrm{bc}^{*}$ & $0,00033 \mathrm{~d}$ & $0,00024 \mathrm{~d}$ & $0,00022 \mathrm{~d}$ & $0,00018 \mathrm{~d}$ & $0,00013 \mathrm{~d}$ \\
\hline Schw: & & $0,00114 \mathrm{c}$ & $26 \mathrm{~d}$ & $23 \mathrm{~d}$ & $0,00025 \mathrm{~d}$ & $0,00021 \mathrm{~d}$ & $0,00015 \mathrm{~d}$ \\
\hline $\begin{array}{l}\text { Oberkulmer } \\
\text { Rotkorn }\end{array}$ & & $0,00179 \mathrm{~b}$ & $0,00028 \mathrm{~d}$ & $0,00020 \mathrm{~d}$ & $0,00021 \mathrm{~d}$ & $0,00020 \mathrm{~d}$ & $0,00011 \mathrm{~d}$ \\
\hline Ostro & & $0,00235 \mathrm{a}$ & $0,00033 \mathrm{~d}$ & $0,00027 \mathrm{~d}$ & $0,00025 \mathrm{~d}$ & $0,00022 \mathrm{~d}$ & $0,00014 \mathrm{~d}$ \\
\hline & Row & $0,00288 \mathrm{~A}^{* *}$ & $0,00033 \mathrm{BC}$ & $0,00021 \mathrm{C}$ & $0,00022 \mathrm{BC}$ & $0,00020 \mathrm{C}$ & $0,00015 \mathrm{C}$ \\
\hline & Inter-row & $0,00049 \mathrm{~B}$ & $0,00027 \mathrm{BC}$ & $0,00026 \mathrm{BC}$ & $0,00025 \mathrm{BC}$ & $0,00021 \mathrm{C}$ & $0,00012 \mathrm{C}$ \\
\hline
\end{tabular}

*a, b, c, d-homogeneous groups for the cultivar $\mathrm{x}$ depth interaction based on the Duncan test

$* * \mathrm{~A}, \mathrm{~B}, \mathrm{C}-$ homogeneous groups for the collection site $\times$ depth interaction based on the Duncan test 
Table 4. Index values of specific root length (SRL).

\begin{tabular}{|c|c|c|c|c|c|c|c|c|}
\hline \multirow[b]{2}{*}{ Cultivar } & \multirow{2}{*}{$\begin{array}{l}\text { Collection } \\
\text { site }\end{array}$} & \multicolumn{6}{|c|}{ SRL $\left(\mathrm{cm}^{-1} \mathrm{~g}^{-1}\right)$ for the depth } & \multirow{2}{*}{$\begin{array}{l}\text { Mean for } \\
\text { cultivar } \\
\left(\mathrm{cm}^{-1} \mathrm{~g}^{-1}\right)\end{array}$} \\
\hline & & $0-5 \mathrm{~cm}$ & $5-10 \mathrm{~cm}$ & $10-15 \mathrm{~cm}$ & $15-20 \mathrm{~cm}$ & $20-25 \mathrm{~cm}$ & $25-30 \mathrm{~cm}$ & \\
\hline Franckenkorn & & 9127,4 & 13028,8 & 13204,8 & 12303,9 & 12825,9 & 11897,2 & $12064,7 \mathrm{c}^{*}$ \\
\hline Schwabenkorn & & 10708,6 & 15197,5 & 13097,9 & 13846,5 & 14242,0 & 12653,3 & $13291,0 \mathrm{~b}$ \\
\hline $\begin{array}{c}\text { Oberkulmer } \\
\text { Rotkorn }\end{array}$ & & 9299,6 & 16086,6 & 16044,6 & 16324,0 & 15493,2 & 15993,8 & $14873,6 \mathrm{a}$ \\
\hline \multirow[t]{3}{*}{ Ostro } & & 7669,18 & 14368,4 & 13129,3 & 14612,5 & 14777,4 & 13074,2 & $12938,5 \mathrm{~b}$ \\
\hline & Row & $\begin{array}{c}4357,6 \\
\mathrm{D}^{* *}\end{array}$ & $\begin{array}{c}14109,9 \\
\mathrm{ABC}\end{array}$ & $\begin{array}{c}14405,8 \\
\mathrm{ABC}\end{array}$ & $\begin{array}{c}14866,7 \\
\mathrm{AB}\end{array}$ & $\begin{array}{c}14259,0 \\
\text { ABC }\end{array}$ & $\begin{array}{c}13759,7 \\
\mathrm{ABC}\end{array}$ & \\
\hline & Inter-row & $\begin{array}{c}13759,7 \\
\text { ABC }\end{array}$ & $\begin{array}{c}15230,7 \\
\text { A }\end{array}$ & $\begin{array}{c}13332,5 \\
\text { BC }\end{array}$ & $\begin{array}{c}13676,7 \\
\mathrm{ABC}\end{array}$ & $\begin{array}{c}14410,3 \\
\mathrm{ABC}\end{array}$ & $\begin{array}{c}13049,6 \\
\mathrm{C}\end{array}$ & \\
\hline
\end{tabular}

$* a, b, c, d-$ homogeneous groups for cultivars based on the Duncan test

$* \mathrm{~A}, \mathrm{~B}, \mathrm{C}-$ homogeneous groups for the collection site $\times$ depth interaction based on the Duncan test

Analysis of the architecture of a root system indicates the importance of root diameter. It is directly linked to the level of biomass accumulation in the roots [19]. The diameter influences the possible root length and number of roots in the system [20]. Root systems with particularly high number of very fine roots, formed by numerous plant species, especially monocotyledons, result from optimization of the root length to mass (nutrient reservoir) ratio, determining the absorption surface. Thin roots posses limited capability to penetrate soil due to their lower length [21]. The root diameter is likely to have an influence on the efficiency of water transport to the stem via the vascular system. Longitudinal flow resistance increases in fine roots.

The mean root diameter index (MD) for the tested spelt cultivars exhibited variability depending on the cultivar and depth. Its greatest value, amounting to 0.189 mm was determined for the Ostro cultivar at the depth 0 $5 \mathrm{~cm}$. For the remaining cultivars, in the same layer of soil, the MD index attained lower and similar values, remaining at the average level of $0.022 \mathrm{~mm}$. All tested objects formed thinnest roots in the layer
5-10 cm. The mean spelt root diameter also depended on the sample collection site. Considering both depth and root sample collection site, its greatest diameter was recorded in row at depth $0-5 \mathrm{~cm}$ (Table 5). Greater root diameter in the surface layer and in the row is likely linked to the greatest share of thicker initial and seminal roots. Corneo et al., [18], who tested root systems of different genotypes of wheat determined that in the soil layer $0-30 \mathrm{~cm}$, the MD values remain in the range from 0.25 to $0.40 \mathrm{~mm}$. The spelt root diameter is lower, in the arable layer to the depth of $30 \mathrm{~cm}$ it remained in the range from to $0.18 \mathrm{~mm}$. As mentioned earlier, the root system characterized by a low diameter of the basic roots creating the system, has a greater absorbing surface and absorption capabilities. But, fine roots have a limited range in the vertical soil profile, limiting the capacity to absorb water from deeper soil layers in deeper layers of soil during prolonged droughts. In the case of the tested spelt cultivars, this phenomenon is exhibited by the values of the RLD and RDM indexes. Their considerably decrease was marked already from the depth of $5 \mathrm{~cm}$.

Table 5. Values of the mean rood diameter (MD) index.

\begin{tabular}{|c|c|c|c|c|c|c|c|}
\hline \multirow{2}{*}{ Cultivar } & \multirow{2}{*}{$\begin{array}{l}\text { Collection } \\
\text { site }\end{array}$} & \multicolumn{6}{|c|}{ MD (mm) for the depth } \\
\hline & & $0-5 \mathrm{~cm}$ & $5-10 \mathrm{~cm}$ & $10-15 \mathrm{~cm}$ & $15-20 \mathrm{~cm}$ & $20-25 \mathrm{~cm}$ & $25-30 \mathrm{~cm}$ \\
\hline Franckenkorn & & $0,169 \mathrm{bc}^{*}$ & $0,127 \mathrm{ijkl}$ & 0,129 hijk & 0,135 fghijk & 0,137 fghij & 0,143 efgh \\
\hline Schwabenkorn & & $0,159 \mathrm{~cd}$ & $0,124 \mathrm{ijkl}$ & 0,138 fghi & 0,138 fghi & $0,146 \mathrm{defg}$ & $0,155 \mathrm{de}$ \\
\hline $\begin{array}{l}\text { Oberkulmer } \\
\text { Rotkorn }\end{array}$ & & $0,174 \mathrm{~b}$ & 0,1 & 0,12 & 0,1 & 0,135 fghijk & 0,133 ghijk \\
\hline Ostro & & $0,189 \mathrm{a}$ & $0,122 \mathrm{jkl}$ & $0,126 \mathrm{ijkl}$ & $0,131 \mathrm{hijk}$ & 0,135 fghijk & $0,148 \mathrm{def}$ \\
\hline & Row & $0,221 \mathrm{~A}$ & $0,124 \mathrm{FG}$ & $0,127 \mathrm{EFG}$ & $0,130 \mathrm{DEF}$ & $0,139 \mathrm{D}$ & $0,143 \mathrm{BC}$ \\
\hline & Inter-row & $0,125 \mathrm{EFG}$ & $0,120 \mathrm{G}$ & $0,130 \mathrm{DEF}$ & $0,134 \mathrm{CDE}$ & $0,139 \mathrm{D}$ & $0,146 \mathrm{~B}$ \\
\hline
\end{tabular}

$*_{\mathrm{a}}, \mathrm{b}, \mathrm{c}, \mathrm{d}, \mathrm{e}, \mathrm{f}, \mathrm{g}, \mathrm{h}, \mathrm{i}, \mathrm{j}, \mathrm{k}, \mathrm{l}$ - homogeneous groups for the cultivar $\mathrm{x}$ depth interaction based on the Duncan test

$* * A, B, C, D, E, F, G-$ homogeneous groups for the collection site $\times$ depth interaction based on the Duncan test

RLD is an important character of plant root system, changing with water availability. If it is unlimited, the RLD values may be higher in the surface layer of soil, yet during prolonged droughts it may also attain higher values in the deeper layers of the soil profile [22].
Values of the index constitute a basic information on the capability of a root system to utilize the water and nutritional resources of soil. The literature data shows that the critical value of a RLD, sufficient for the use of these resources is $1 \mathrm{~cm} \mathrm{~cm}^{-3}[23,24,25]$. High 
variability of RLD depending on the moisture conditions of soil results in different publications, concerning the same species a wide range of the values can be found. According to Gregory et al., [26], Barraclough et al., [24, 27], the root length density (RLD) for the winter wheat cultivars in soil to depth of $20 \mathrm{~cm}$ is from 5.6 to $10 \mathrm{~cm}$ $\mathrm{cm}^{-3}$ and from 0.4 to $1.5 \mathrm{~cm} \mathrm{~cm}^{-3}$ at the depth from 80 $100 \mathrm{~cm}$. Pillinger et al., [28] report that in the surface layer of soil RLD, also in the case of winter wheat may attain values at the level of $7 \mathrm{~cm} \mathrm{~cm}^{-3}$ and $0.2 \mathrm{~cm} \mathrm{~cm}^{-3}$ at depth 80-100 $\mathrm{cm}$. Hoad et al., [29] state that in the arable layer of soil, at good root development of winter heat, the RLD amounts from 3 to $6 \mathrm{~cm} \mathrm{~cm}^{-3}$ and below 1 $\mathrm{cm} \mathrm{cm}^{-3}$ at depth exceeding $40 \mathrm{~cm}$. In the case of inferior root development, RLD may amount to less than $1 \mathrm{~cm}$ $\mathrm{cm}^{-2}$, also in the arable layer. In Australia, Atta et al., [30], who published results of study concerning 15 genotypes, report that the values of the RLD index in the upper $15 \mathrm{~cm}$ soil layer remain in the range from 0.6 to 2 $\mathrm{cm} \mathrm{cm}{ }^{-3}$, whereas Narayanan et al., [31], who examined 30 spring wheat genotypes state that in the soil layer between 0 to $30 \mathrm{~cm}$ the values of the index range from 0.86 to $1.83 \mathrm{~cm} \mathrm{~cm}^{-3}$.
In the case of the tested spelt cultivars in the layer 0$30 \mathrm{~cm}$, values of the tested index remained in the range from $0.179 \mathrm{~cm} \cdot \mathrm{cm}^{-3}$ in the inter-row at depth $25-30 \mathrm{~cm}$ to 1.388 for row and surface layer $0-5 \mathrm{~cm}$ (Table 6).

A statistical analysis of the values of the root length density (RLD) index did not exhibit significant differences in this field between the tested spelt cultivars at individual depths. The mean value of the index was $0.467 \mathrm{~cm} \cdot \mathrm{cm}^{-3}$. The root length density exhibited variation depending on the depth and site of sample collection. The highest values of the index were obtained in row at depth $0-5 \mathrm{~cm}$, where its mean value was 1.388 $\mathrm{cm} \cdot \mathrm{cm}^{-3}$. On the other hand, the lowest values were recorded at the depth from 20 to $30 \mathrm{~cm}$, both in the row as well as in the inter-row (Table 6). These results demonstrate that to the depth of $5 \mathrm{~cm}$ the root systems of the tested cultivars may exhibit satisfactory water and nutrient absorption capacity, yet it solely applies to a thin layer located near the plant, as in the inter-row the RLD index assumes values below $1 \mathrm{~cm} \cdot \mathrm{cm}^{-3}$ for the same depth.

Table 6. Values of the root length density (RLD) index.

\begin{tabular}{|c|c|c|c|c|c|c|c|}
\hline \multirow{2}{*}{ Cultivar } & Collection & \multicolumn{7}{|c|}{ RLD $\left(\mathbf{c m}^{-\mathbf{c m}}\right.$ ) for the depth } \\
\cline { 3 - 8 } & site & $\mathbf{0 - 5} \mathbf{~ c m}$ & $\mathbf{5 - 1 0} \mathbf{~ c m}$ & $\mathbf{1 0 - 1 5} \mathbf{~ c m}$ & $\mathbf{1 5 - 2 0} \mathbf{~ c m}$ & $\mathbf{2 0 - 2 5} \mathbf{~ c m}$ & $\mathbf{2 5 - 3 0} \mathbf{~ c m}$ \\
\hline Franckenkorn & & 1,023 & 0,504 & 0,370 & 0,342 & 0,289 & 0,192 \\
\hline Schwabenkorn & & 0,862 & 0,477 & 0,353 & 0,361 & 0,320 & 0,204 \\
\hline $\begin{array}{c}\text { Oberkulmer } \\
\text { Rotkorn }\end{array}$ & & 1,047 & 0,552 & 0,416 & 0,421 & 0,334 & 0,214 \\
\hline Ostro & & 1,069 & 0,574 & 0,393 & 0,388 & 0,328 & 0,182 \\
\hline & \multirow{2}{*}{ Row } & $1,388 \mathrm{a}$ & $0,546 \mathrm{bc}$ & $0,365 \mathrm{def}$ & $0,364 \mathrm{def}$ & $0,309 \mathrm{efg}$ & $0,217 \mathrm{fg}$ \\
\cline { 3 - 8 } & Inter-row & $0,612 \mathrm{~b}$ & $0,508 \mathrm{bcd}$ & $0,401 \mathrm{cde}$ & $0,391 \mathrm{cdef}$ & $0,327 \mathrm{efg}$ & $0,179 \mathrm{~g}$ \\
\hline
\end{tabular}

*a, b, c-homogeneous groups for the collection site $\mathrm{x}$ depth interaction based on the Duncan test

\section{Conclusions}

Analysis of the obtained study results allows to formulate the following conclusions:

1. The highest value of the RDM and MD indexes characterized the root system of the Ostro cultivar at the depth $0-5 \mathrm{~cm}$.

2. Spelt of the OberkulmerRotkorn cultivar is distinguished among the remaining objects the greatest value of the specific root length (SRL) index, amounting to $14873.6 \mathrm{~cm} \cdot \mathrm{g}^{-1}$.

3. The root length density (RLD) index in the layer 0 $30 \mathrm{~cm}$ assumes similar values for all tested spelt cultivars. Its mean value remains at the level of $0.467 \mathrm{~cm} \cdot \mathrm{cm}^{-3}$.

4. For all tested spelt cultivars, the RDM, MD, RLD indexes assume greatest values in rows at depth 0-5 $\mathrm{cm}$.

\section{References}

1. S. Stankowski, G. Hury, A. Makrewicz, G. JurgielMałecka, M. Gibczyńska. Inż. Ekolog., 49 (2016)

2. H. Sulewska, W. Koziara, K. Panasiewicz, G. Ptaszyńska, M. J. Morozowska. Res. Appl. Agric. Engng. 53, 4 (2008)

3. J. Tyburski, M. Babalski. (CDR w Brwinowie Oddział w Radomiu, Radom, 2006)

4. S. M. Rich, M. Watt. J. Exp. Bot. 64, 5 (2013)

5. A. Elazab, G. Molero, M. Dolores Serret, J. Luis Araus. Funct. Plant Biol., 39 (2012)

6. M. A. Hajabbasi.. J. Agric. Sci. Technol., 3 (2001)

7. K.G Mandal, K.M. Hati, A.K. Misra, P.K. Ghosh, K.K. Bandyopadhyay. Jour. Agric. Physics. 3, $(1,2)$ (2003)

8. G. Den Herder, G. Van Isterdael, T. Beeckman, I. De Smet. Trends Plant Sci. 15, 11 (2010)

9. B. M. Atta, T. Mahmood, R. M. Trethowan. Aust. J. Crop. Sci. 7, 13 (2013)

10. W. Bohm. Springer-Verlag (Germany, Berlin 1979)

11. A.J.M. Smucker, S.L. Mc Burney, A.K. Srivastova. Agron J., 74 (1982) 
12. J. Bauhus, Ch. Messier. Agron. J., 91 (1999)

13. American Society of Agricultural Engineers. Soil cone penetrometer. ASAE Standard S313.3, (2002)

14. W. Larcher. Physiological plant ecology, 3 (1995)

15. D.M. Eissenstat, C.E. Wells, R.D. Yanai, J.L. Whitbeck. New Phytol.147, 1 (2000)

16. A. Fitter. Plant Roots, 3 (2002)

17. A. K. Løes, T. S. Gahoonia. Euphytica., 137 (2004)

18. P. E. Corneo, C. Keitel, M. A. Kertesz, F. A. Dijkstra. AgrEcosyst Environ., 246 (2017)

19. D.M. Eissenstat. J. Plant Nutr. 15, (6-7) (1992)

20. L.P.R. Bidel, L. Pagès, L.M. Rivière, G. Pelloux, J.Y. Lorendeau. Ann. Bot. 85, 6 (2000)

21. L.J. Clark, A.H. Price, K.A. Steele, W.R. Whalley. Funct. Plant. Biol. 35, 11 (2008)

22. A. Blum. Aust. J. Agric. Res. 56, 11 (2005)

23. M. van Noordwijk Proceedings of the third ISRR (symposium Austria, 1983)

24. P.B. Barraclough, H. Kuhlmann, A.H. Weir. J. Agron. Crop. Sci., 163 (1989)

25. C. White, R. Sylvester-Bradley, P.M. Berry. J. Exp. Bot. 66, 8 (2015)

26. P.J. Gregory, M. McGowan, P.V. Biscoe, B. Hunter. J AgrSci-Cambridge, 91 (1978)

27. P.B. Barraclough, A.H. Weir, H. Kuhlann. Developments in agricultural and managed forest ecology, 24 (1991)

28. C. Pillinger, N. Paveley, M.J. Foulkes, J. Spink. Plant Pathology 54, 4 (2005)

29. S.P. Hoad, G. Russell, P.S. Kettlewell, M. Belshaw. HGCA Project Report, 351 (2004)

30. B.M. Atta, T. Mahmood, R.M.Trethowan. Aust. J. Crop. Sci. 7, 13 (2013)

31. S. Narayanan, A. Mohan, K.S. Gill, P. V. V. Prasad. PLoS ONE 9, 6 (2014) 